\title{
Bulanık Sürece Dayalı Faaliyet Tabanlı Maliyetleme Sistemi
}

\author{
Muhsin ÇELIKK*
}

\section{ÖZET}

Faaliyet tabanl maliyet tasarımları analizde ve değişkenlerin tahmininde hatalara büyük ölçüde duyarlı değildir. Geleneksel faaliyet tabanlı maliyet modelinin eksik olan önemli unsurlarını tamamlamak amacıyla Kaplan ve Anderson (2004) "Sürece Dayalı Faaliyet Tabanlı Maliyet" olarak adlandırllan ikinci nesil faaliyet tabanl maliyet sistemini önermiştir. Bu sistem, maliyet havuzlarında harcanan zaman yükleme ölçüleri esasına dayanmaktadır. Sürece dayal faaliyet tabanlı maliyet sistemi; doğru ve güvenilir zaman yükleme ölçülerinin kullanılamaması, toplama ve hesaplama yöntemi üzerinden veri güncelleme zorluklarının bulunması ve büyük hacimde verilerin olmasl gibi tahsis edilen maliyetlerin hesaplanmasinda bazı zorluklara sahiptir. Ayrica, sistem meydana gelebilecek herhangi bir faaliyet değişikliğinde yetersiz bilgiler dolayısıyla doğru karar vermeye duyarlı değildir. Bulanık küme teorisi belirsiz çevre ortamında karar almakta akll yürütme ile ilgilenen mantıksal bir yaklaşımdır. Bu çalışma, maliyetleme konusunda bulanı sürece dayalı faaliyet tabanlı maliyet adıyla yeni bir çerçeve önermektedir. Çalışmada, üçgen bulanık sayı tekniği kullanılarak bulanıklaştırma yapılmış ve sürece dayalı faaliyet tabanlı maliyet sistemi için yeni bir mekanizma önerilmiştir.

Anahtar Kelimeler: Sürece Dayalı Faaliyet Tabanlı Maliyet, Bulanık Mantık, Üçlü Bulanık Sayılar, Bulanık Sürece Dayalı Faaliyet Tabanlı Maliyet

JEL Sinıflandırması: M41, C60.

\section{Fuzzy Time-Driven Activity-Based Costing}

\section{ABSTRACT}

Activity-based costing designs are not greatly sensitive to errors in estimating of variables. Kaplan and Anderson (2004) suggested the second generation of the activity based costing system, called as "Time-Driven Activity-Based Costing" in order to complete important missing components of the conventional activity based costing model. This system is mainly based on the time drivers spent on cost pools. Time-driven activity-based costing has some difficulties in calculating of assigned cost such as lack of accurate and reliable time drivers, difficulties of collecting and updating data for calculation procedure, and huge volume of data. Furthermore, it is not sensitive to give correct decisions because of weak information when there might be any change on activity. The fuzzy sets theory is a logical approach is related to reasoning in management of uncertainty environments. This paper suggested a new framework on costing named as fuzzy time-driven activity. In the study, a fuzzification operation was carried out by using the triangular fuzzy number mechanism and suggested a new fuzzification technique for the time-driven activity-based costing systems.

Key Words: Time-Driven Activity-Based Costing, Fuzzy Logic, Triangular Fuzzy Number, Fuzzy Time-Driven Activity-Based Costing

Jel Classification: M41, C60.

\footnotetext{
*Doç. Dr. Muhsin ÇELİK, Pamukkale Üniversitesi, İİBF, İşletme Bölümü, muhsincelik@pau.edu.tr
} 


\section{GíRiş}

Maliyetleme, finansal muhasebenin derlediği verilerden toplam ve birim maliyeti hesaplama işlemidir. (Büyükmirza, 2009: 34). Maliyetleme, tüm maliyet yöntemlerinde ürünlerin, işlemlerin, süreçlerin ve hizmetlerin maliyetlerini tespit etmek için farklı yaklaşımlar kullandığından çoğu zaman bir "teknik" olarak adlandırılır (Gençoğlu, 2008: 1). Maliyetleme, rutin olarak gün gün maliyetlerin belirlenmesi ve maliyet yükleme ölçülerine atanması dolayısıyla "işlem" olarak da adlandırılır. Diğer bir deyişle maliyetleme, bir firmanın farklı operasyonlarında veya üretimin çeşitli aşamalarında harcamaların tahsisi, sınıflandırılması ve kaydının yapılmasıdır (Mortaji vd., 2013: 63). En tanınmış maliyet sistemi, farklı süreçlerin dolaylı maliyetlerinin mal ve hizmet gibi maliyet objelerine dağıtımında statik ve tek maliyet oranının kullanıldığı geleneksel maliyet sistemidir. Sabit dolaylı giderlerin küçük ve az olduğu, durağan ortamlarda belirli senaryolarda geleneksel maliyet sistemi iyi çalışır. Ancak daha karmaşık ortamlarda yanlış ürün maliyeti tahminlerine yol açar (Siguenza-Guzman vd., 2014: 77). Burada söz edilen karmaşık ortam ile; farklı şekillerde hizmet gerektiren fazla sayıdaki müşteri, farklı şekillerde tasarlanan fazla sayıda ürün, farklı şekillerde kullanılan fazla miktarda kaynak, farklı şekillerde temin gerektiren fazla sayıda tedarikçi; farklı veri sistemleri ve fazla sayıda operasyonel veri kastedilmektedir (Yükçü ve Gönen, 2009: 21).

Maliyetleme teknikleri arasında en yaygın olan Faaliyet Tabanlı Maliyet (FTM), yenilikçi yönetim muhasebesi uygulamalarından biridir. FTM ilk kez açıkça 1987 yllında William J. Bruns ve Robert S. Kaplan'ın Muhasebe ve Yönetim kitabında bir bölüm olarak tanımlanmış ve yer almıştır. Robin Cooper ve Robert S. Kaplan 1988 yılında Harvard Business Review'de yayınlamaya başladıkları bir dizi makalelerinde faaliyet tabanlı yönetim ve maliyet kavramlarına dikkat çekmişlerdir (Mortaji vd., 2013: 63). Geleneksel maliyet sistemlerinde işletmeye ait genel üretim giderleri öncelikle üretim maliyet merkezlerine aktarılmakta sonraki adımda ise maliyet merkezlerinde toplanan maliyetler makine saati ve direkt işçilik saati gibi taşıyıcılar vasıtasıyla ürünlere yüklenmektedir. FTM yönteminde ise, kaynak giderleri, maliyet merkezleri yerine işletmede ortaya çıkan faaliyetlere, farklı maliyet yükleme oranları yardımıyla dağıtılmakta, sonrasında ise buralarda toplanan maliyetler, faaliyetlerle ilgili çeşitli maliyet yükleme oranları vasıtasıyla ürünlere, hizmetlere ve müşterilere aktarılmaktadır (Cooper ve Kaplan, 1992: 1, Özyürek ve Dinç, 2014: 348).

Sürece dayalı faaliyet tabanlı maliyetleme, işletmelerin maliyetlerini ve kârlılıklarını; müşteri, ürün ve hatta sipariş gibi daha bir çok alt seviyede sürdürülebilir şekilde bölümleyip yönetmelerini mümkün kılmakta, bu nedenle de kurumsal performansın çok daha etkin biçimde yönetilebilmesine olanak tanımaktadır (Yükçü ve Gönen, 2009: 21). Bu çalışmada Sürece Dayalı Faaliyet Tabanlı Maliyetlemenin (SDFTM) gelişimi ve SDFTM hakkında kısaca bilgi verildikten sonra bulanık küme kavramından bahsedilecek, ardından bulanık sürece dayalı faaliyet tabanlı maliyetleme konusu bulanık üçgen sayılar kullanılarak örnek üzerinden işlenecektir. 


\section{SÜRECE DAYALI FAALIYET TABANLI MALIYETLEME}

Kurum veya kuruluşlarda belirli faaliyetlere odaklanmak ve faaliyetlere ait maliyetlerin düşürülmesi, yöneticiler için oldukça önemli bir konudur. Son yıllarda faaliyet tabanlı maliyetlemenin yönetim amaçlı olarak kullanılması ile bu problemin çözülebileceği vurgulanmaktadır. Faaliyet tabanlı yönetimde bilgiler sadece muhasebe sistemlerinden gelmemektedir. Üretim kontrol sistemleri, satış emri sistemleri ve mühendislik sistemlerinden de alınan verilerle işletme genelinde entegre bir bilgi sistemi oluşturulmaktadır. Bu entegre bilgi sistemi kurum veya kuruluşlara ürün-hizmet hattı, müşteri ilişkileri, işlemlerin geliştirilmesi, pazar bölümlendirmesi, ürün, müşteri karışımı gibi birbirinden farklı, verimliliği ve kârı arttıracak stratejik ve operasyonel kararların alınmasına yardımcı olmaktadır (Özyürek ve Dinç, 2014: 348-349). Bunun için işletmenin bütün faaliyetleri çok detaylı ve dikkatli bir şekilde incelenmekte, faaliyet sonuçları analiz edilmekte ve en iyi sonuçları sağlayan birimlerle veya diğer işletmelerle karşılaştırmalar yapılmaktadır. Ayrıca çalışanların işletmenin üretim sürecinde daha etkin olmaları desteklenmekte, üretim süreci ile ilgili görüşleri önemsenmekte ve bu doğrultuda değişiklikler yapılabilmektedir. Böylece üretim sürecinde iyileştirmeler yapılmakta, kaynakların optimal kullanımı ve maliyetlerde düşüş sağlanabilmektedir (Karğın, 2013: 28).

Faaliyet analizinde işletme, katma değeri olan ya da olmayan faaliyetleri belirler ve üretim sürecinde katma değeri olmayan faaliyetleri ortadan kaldırır. Maliyete yol açan faktörlerin bir analizini yaparak, yapılan işin daha iyi duruma getirilmesine dair firsatlar elde edebilir. Aynı zamanda faaliyet analizi sayesinde, her bir faaliyetin tamamlanması için ne kadar süre gerektiği, faaliyetlerin verimliliği ve faaliyet süreçleri ile ilgili bilgilere de ulaşabilir (Özyürek ve Dinç, 2014: 349). Çalışanların zamanlarını, faaliyetler üzerinde nasıl harcadıkları konusu, aslında birçok maliyet sisteminin araştırma konusu olmuştur. Zaman tahminleri, maliyet yönetiminde kaynak maliyetlerinin faaliyetlere aktarılması noktasında kullanılan önemli süreç etkenleri olarak karşımıza çıkar (Çapuk, 2012: 73).

Faaliyet tabanlı maliyet yönteminin faydalarının yanında, uygulamada bazı zorluklarla karşılaşılmıştır. Bu zorluklar; personel görüşmeleri ve anket çalışmalarının zaman alıcı olması ve aynı zamanda yöntemin kurulumunun pahalı olması, mamullerin, müşterilerin ve faaliyetlerin değiştiği ortamlarda modelin güncellenmesinin zaman alması, FTM temelli maliyet yönetim sistemleri ile işletmenin diğer bilgi sistemleri arasında entegrasyon veya eşgüdüm eksikliği, büyük işletmelerde bu sistemin uygulanmasının karmaşık olması, yönetim desteğinin yeterli olmayışı, yöntemin uygulanması sürecinde tüm personelin eğitilmesinin zorlukları şeklinde sıralanabilir. Faaliyet tabanlı maliyet yönteminin eksikliklerini ortadan kaldırmak amacıyla sistemin özelliklerini kaybetmeden yeni bir sistem geliştirilmiştir (Karğın, 2013: 30, Özyürek ve Dinç, 2014: 349).

Sürece Dayalı Faaliyet Tabanlı Maliyet (SDFTM) adını alan bu yeni yöntemin kolay ve hızlı uygulanabilme, ERP (Enterprise Resource Planning-kurumsal kaynak planlama) ve CRM (Customer Relationship Management-müşteri ilişkileri yönetimi) sistemlerinden veri 
besleme ve bu sistemlerle entegrasyon sağlayabilme, sürdürülebilirliği ve düşük maliyetli ve hızlı güncellenmesi, İşletme çapında modellenebilme, belirli siparişler, süreçler, tedarikçiler ve müşteriler için belirli özelliklerin kolay dahil edilebilmesi, verimlilik ve kapasite kullanım işlerliği açısından şeffaflık, öngörülen sipariş miktarı ve karmaşıklığına dayalı gelecekteki kaynak taleplerini öngörebilme kabiliyeti gibi bir çok avantajı söz konusudur (Kaplan ve Anderson, 2003:15-16).

İşletme faaliyetlerinde harcanan zamanı dikkate alan ve işletmede oluşan boş zamanı maliyet hesaplamalarına katan yeni bir yöntem olan SDFTM sisteminin (Time-Driven Activity-Based Costing) kullanılmasının daha doğru bilgi elde edilmesini sağlayacağ düşünülmektedir. Bu çerçevede, faaliyet tabanlı maliyet sistemi yerine atıl kapasitenin neden olduğu farklılıkların da anlaşılmasını sağlayacak SDFTM sisteminin kullanılmasının analiz sonucunu olumlu etkileyeceği düşünülmektedir. Zamanın verimli kullanılması, işletme kaynaklarının kapasitelerinin iyi yönetilmesine bağlıdır. İşletmelerde operasyonel süreçlerin verimliliğinde, faaliyetlerin etkinliğinde, personel ve donanım performans ölçümlerinde, kapasite ve maliyet yönetiminde başarı sağlanmasında ve bu başarının devamlı olmasında, zaman, önemli bir unsur olarak karşımıza çıkmaktadır (Kırlığlu ve Atalay, 2014: 102).

Doğruya en yakın sonuçları vermek üzere tasarlanmış ve geliştirilmeye devam eden maliyet sistemlerinden elde edilen göreceli doğru maliyet bilgisi, maliyet sisteminde sebepsonuç ilişkisiyle tanımlanan maliyet etkenlerinin nitelik ve nicelik olarak iyileştirilmesine bağlıdır. Doğruluk seviyesi yüksek kabul edilen bir maliyetleme sisteminden beklenen hayati özellikler, maliyet etkin, yalın ve esnek olmasıdır. İşletmelerin bu ihtiyacını karşılamak üzere geliştirilen sürece dayalı faaliyet tabanlı maliyet, geleneksel faaliyet tabanlı maliyetlerin çizgisinde devam ederken, bahsedilen bu ek özellikleri de kapsamaktadır (Çapuk, 2012: 68).

Zamana dayalı maliyetleme süreci bir bölüm tarafından gerçekleştirilen bütün faaliyetleri analiz eder ve faaliyetler için gerekli olan toplam zaman ile bölümün çalışanları için mevcut bulunan toplam zaman arasındaki farkı otomatik olarak ortaya çıkartır. Bu da daha iyi bir kapasite yönetiminin bir amaç olarak edinildiği FTM programları için SDFTM sistemini daha uygun bir metot haline getirir. SDFTM atıl kapasite ile fiili kapasiteyi ayırdı ğ için firmalara işgücü zaman etkinliği hakkında düzenli bilgi sunar (Çapuk, 2012: 70).

Faaliyet tabanlı maliyetleme yönteminin; veri toplama ve hazırlama sürelerinin uzunluğu, sistem güncelleştirmelerinin karmaşıklığı, faaliyetlerin ne kadar sürede yapılacağına ilişkin çalışan personelle yapılan anketlerin her faaliyet değiştiğinde tekrar yapılması zorunluluğu, faaliyet sayısının çokluğu ile birlikte bu faaliyetlerin karmaşıklı̆̆ kapasiteyi göstermeyen zaman ifadeleri gibi eksiklikleri bulunmaktadır. Bu eksiklikleri gidermek amacıyla FTM'nin tasarımcıları Kaplan ve Anderson SDFTM'yi geliştirmişlerdir (Mortaji vd., 2013: 64). 
Şekil 1: Maliyetleme Modellerinin Gelişimi

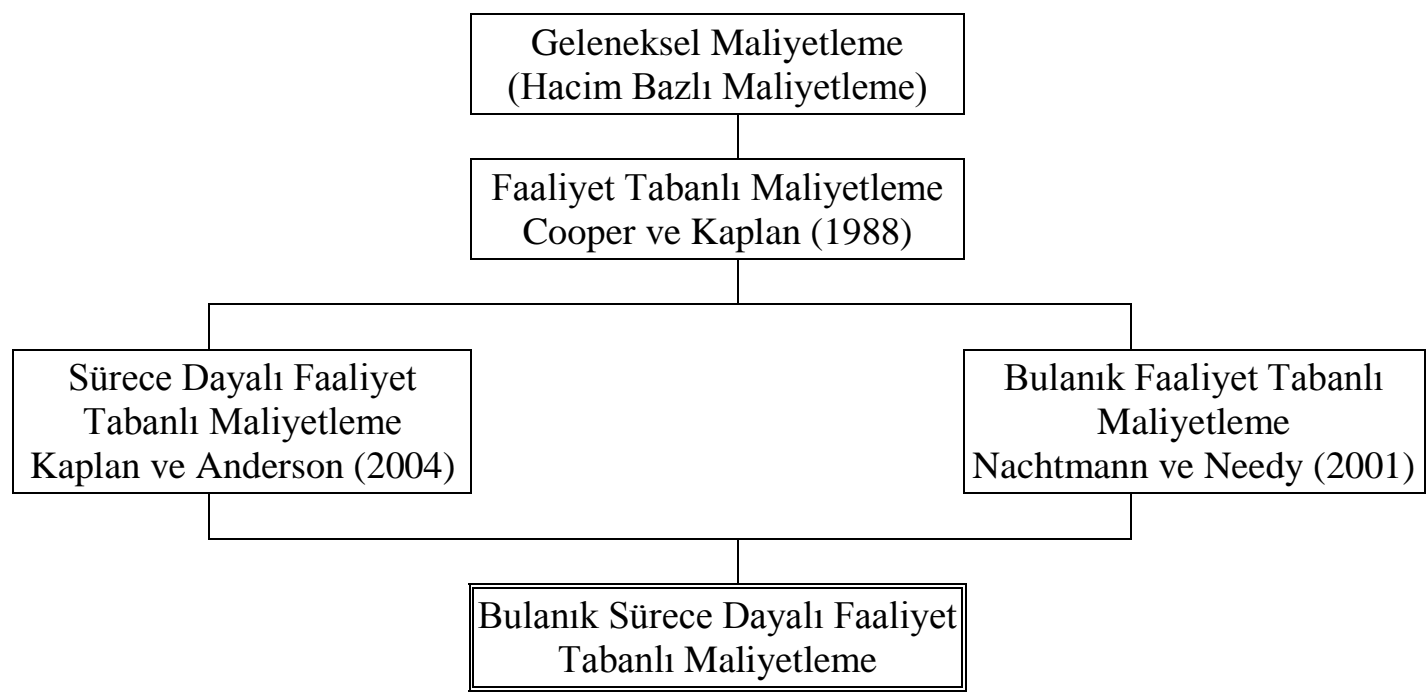

Kaynak: Chansaad vd., 2012.

SDFTM modeli faaliyeti tanımlama aşamasını ortadan kaldırır. Böylece çok amaçlı faaliyetlerin maliyetlerini birim maliyeti bulmak için uygulamaya ihtiyaç kalmaz. Faaliyete Dayalı Maliyet yönteminde iş süreçlerindeki değişimlerden ve iş dinamizminden kaynaklanan güncelleme çalışmaları için şirket çalışanlarına zamanlarını hangi faaliyetlere ve nasıl kullandıklarına dair anket yapılır ve faaliyetlerin kaynak kullanımı hesaplaması tekrar yapılır

Tablo 1: Faaliyet Tabanlı Maliyetleme ve Sürece Dayalı Faaliyet Tabanlı Maliyetleme Yöntemlerinin Karşılaştırılması

\begin{tabular}{|c|c|c|c|}
\hline \multicolumn{2}{|c|}{ Faaliyet Tabanlı Maliyetleme } & \multicolumn{2}{|c|}{ Sürece Dayalı Faaliyete Tabanlı Maliyetleme } \\
\hline 1.Adım & $\begin{array}{l}\text { Genel üretim giderlerine faaliyetlere uygun } \\
\text { farklı maliyet havuzları belirler ve } \\
\text { sinıflandırır. }\end{array}$ & 1.Adım & $\begin{array}{l}\text { Bölümleri (kaynak grupları) tanımlar. } \\
\text { (örneğin bakım departmanı, üretim } \\
\text { departmanları) }\end{array}$ \\
\hline 2.Adim & $\begin{array}{l}\text { Bir kaynak yükleme ölçüsü kullanarak } \\
\text { maliyet havuzuna kaynak maliyetlerini } \\
\text { tahmin ve tahsis eder. }\end{array}$ & 2.Adım & $\begin{array}{l}\text { Her bölümün toplam kaynak maliyetini } \\
\text { tahmin eder. }\end{array}$ \\
\hline 3.Adim & $\begin{array}{l}\text { Her maliyet havuzu için maliyet yükleme } \\
\text { ölçüleri tespit eder. }\end{array}$ & 3.Adım & $\begin{array}{l}\text { Her bölümün pratik zaman kapasitesini } \\
\text { tahmin eder. }\end{array}$ \\
\hline 4.Adım & $\begin{array}{l}\text { Faaliyet yükleme ölçüsünün pratik hacim } \\
\text { olarak toplam faaliyet giderlerini bölerek } \\
\text { her bir havuz için maliyet yükleme ölçüsü } \\
\text { oranını belirler. }\end{array}$ & 4.Adım & $\begin{array}{l}\text { Pratik zaman kapasitesi ile toplam } \\
\text { kaynak maliyetini bölerek her bölüm için } \\
\text { bir kapasite maliyeti oranı hesaplar. }\end{array}$ \\
\hline \multirow[t]{2}{*}{ 5.Adım } & $\begin{array}{l}\text { Faaliyet yükleme ölçüsü tüketimi ile } \\
\text { faaliyet yükleme ölçüsü oranı çarpılarak } \\
\text { ürünlere kaynak maliyetlerini atar. }\end{array}$ & 5.Adım & $\begin{array}{l}\text { Bir zaman denklemi kullanarak her bir } \\
\text { faaliyet için gerekli zamanı belirler. }\end{array}$ \\
\hline & & 6.Adım & $\begin{array}{l}\text { Faaliyeti gerçekleştirmek için gerekli } \\
\text { zaman ile kapasite maliyet oranını çarpar. }\end{array}$ \\
\hline
\end{tabular}

Kaynak: Everaert vd., 2008; Chansaad vd., 2012. 
SDFTM modeli, FTM yönteminde yürütülen masraflı, gereksiz, zaman alıcı ve sübjektif olan anket ve faaliyetlerin kaynak kullanımı işlemlerini önler. SDFTM modeli, kaynakların maliyetlerinin faaliyet ve işlemlere doğrudan tahsis edildiği denklem kullanır. SDFTM modeli bunun için sadece iki parametre tahmin eder (Kaplan ve Anderson, 2003: 7). Bunlar:

- $\quad$ Faaliyet ya da işlemi yürüten departmanın kapasite maliyet oranı: Departmanlardaki kaynak kapasitesinin sağlanması için gerekli olan maliyetin fiili kapasiteye bölünmesiyle bulunur (fiili kapasite üretken iş gücünün teşkil ettiği zaman dilimini ifade eder).

- Departmanda yürütülen faaliyetlerin kapasite kullanım zamanları: departmanlar ya da süreçler tarafından ürün ya da müşteri işlemlerinin gerçekleşmesi için ihtiyaç duyulan kapasite (zaman).

Kapasite Maliyetinin Oranı $=\frac{\text { Tedarik Edilen Kaynak (Kapasite) Maliyeti }}{\text { Tedarik Edilen Kaynakların Pratik Kapasitesi }}$

Sürece dayalı faaliyet tabanlı maliyetlemeyi tarif ve bu konuda daha fazla bilgi edinmek için, günde 8 saat, ayda 25 iş günü ve 65 çalışanın olduğu bir bölüm varsayalım.

$\mathrm{Bu}$ faaliyetlerin fiili (veya tahmini) çalışma miktarları aşağıdaki gibidir:

9.800 adet sipariş alınması

280 adet şikâyetin işlenmesi

500 adet müşterinin kredibilite kontrolü

Uzmanların (yönetimin) tahminleri müşterilerle ilgili faaliyetler için aşağıdaki ortalama birim sürelerin gerekli olduğunu varsayalım:

$\begin{array}{lr}\text { Siparişlerin alınması } & 40 \text { dakika } \\ \text { Şikâyetlerin işlenmesi } & 220 \text { dakika } \\ \text { Müşteri kredibilite kontrolü } & 250 \text { dakika }\end{array}$

Ayrıca bölümün (personel, denetim, bilgi teknolojisi, telekomünikasyon ve doluluk gibi) faaliyetleri gerçekleştirmek için dönem kaynak maliyeti 560.000 TL'dir. Sürece dayalı faaliyet tabanlı maliyetleme ile bulanık sürece dayalı faaliyet tabanlı maliyetlemenin bir faaliyet döneminde bölümün pratik kapasitesinden yararlanma ve bölümün toplam giderinin müşterilere yansıtılmasındaki farkı görebilmek için, Kaplan ve Anderson (2003) tarafından kullanılan bu veriler üzerinden öncelikle teorik kapasiteyi hesaplayalım.

Bu bilgilere göre, erişilebilir kapasite Aylık 13.000 saat $(65 * 8 * 25=13.000)$, ya da 780.000 dakika $(13.000 * 60=780.000)$ olur. Bu 13.000 saat, 780.000 dakika bölümün aylık teorik kapasitesidir.

İşletme ve muhasebede, kapasite genellikle "üst sınır” anlamına gelen bir "kısıtlama"dır. Teorik kapasite, tüm üretim hatlarının her zaman tam verimle çalıştı̆̆ı, aksamanın olmadığı kapasite seviyesidir. Teorik kapasite, üretim hatları üzerindeki herhangi 
bir bakım nedeniyle kesinti veya üretimde çeşitli nedenlerle duraklama olmadığını varsayar. Teorik kapasite seviyelerine gerçek iş dünyasında ulaşılamaz. Ancak, kapasite kullanımında ideal hedefi temsil eder. Pratik kapasite kaçınılamaz bakım onarım, üretim duraklamaları ve tatil gibi kesintileri dikkate alarak teorik kapasiteden düşülerek hesaplanan kapasite seviyesidir (Horngren vd., 2012: 336, Büyükmirza, 2009: 527-529).

Ayrıca, TMS-2 Stoklar standardı muhasebe uygulamalarında tam maliyet yöntemi yerine normal maliyet yönteminin kullanılmasını istemektedir. Bu yöntem, sabit genel üretim giderlerinin üretim kapasitesi yaratan giderlerinden hareket edilerek; bu giderlerin sadece dönem içinde kullanılan kapasiteye ait olan kısmının üretilen ürünlerin maliyetine katılmasını, kullanılmayan kapasiteye ait kısmın ise dönem giderine alınmasını benimsemiştir (Akgün, 2012: 229).

Normal kapasite kullanımı mevsimlik, devresel ve iki üç yıllık eğilimleri içeren bir dönemde ortalama müşteri talebini karşılayan kapasite kullanım düzeyidir. (Horngren vd., 2012: 336, Büyükmirza, 2009: 527-529). Normal kapasite; planlanan bakım onarım çalışmalarından kaynaklanacak kapasite düşüklüğü de dikkate alınarak, normal koşullarda bir veya birkaç dönem veya sezonda elde edilmesi beklenen ortalama üretim miktarını ifade etmektedir.

Sürece dayalı faaliyet tabanlı maliyetlemede ise kapasite, çoğunlukla teorik kapasitenin yüzde 80 - 90 oranları arası pratik kapasite olarak kullanılmaktadır (Kaplan ve Anderson, 2003:6). Bu örnekte, pratik kapasite \% 90'dan $(13.000 * \% 90=11.700 * 60=$ 700.000 dakika) olarak hesaplanır.

Faaliyetin her dakikası için maliyet oranı: 560.000TL / 700.000 dakika $=0,8 \mathrm{TL} / \mathrm{dk}$ olur.

Tablo 2: Bölümün Sürece Dayalı Faaliyet Tabanlı Faaliyet ve Maliyetleri

\begin{tabular}{|l|c|c|c|c|}
\hline Faaliyet & $\begin{array}{c}\text { Her bir ürün için } \\
\text { gerekli zaman } \\
\text { (dakika) (1) }\end{array}$ & $\begin{array}{c}\text { Faaliyet (yükleme } \\
\text { ölçüsü) hacmi } \\
\text { (miktar) (2) }\end{array}$ & $\begin{array}{c}\text { Kullanılan toplam } \\
\text { süre (3) } \\
(3)=(1) *(2)\end{array}$ & $\begin{array}{c}\text { Faaliyetin toplam } \\
\text { maliyeti (4) } \\
(4)=(3) * 0,8\end{array}$ \\
\hline $\begin{array}{l}\text { Siparişlerin } \\
\text { alınmas1 }\end{array}$ & 40 & 9.800 & 392.000 & 313.600 \\
\hline $\begin{array}{l}\text { Sikâyetlerin } \\
\text { işlenmesi }\end{array}$ & 220 & 280 & 61.600 & 49.280 \\
\hline $\begin{array}{l}\text { Müşteri kredibilite } \\
\text { Kontrolü }\end{array}$ & 250 & 500 & 125.000 & 100.000 \\
\hline Kullanılan kapasite & & & 578.600 & 462.880 \\
\hline $\begin{array}{l}\text { Kullanilmayan } \\
\text { kapasite }\end{array}$ & & & 121.400 & 97.120 \\
\hline Toplam & & & 700.000 & 560.000 \\
\hline
\end{tabular}


Sürece Dayalı Faaliyet Tabanlı Maliyetleme ile faaliyet döneminde bölümün pratik kapasitesinden \%82,65 (578.600/700.000) oranında yararlanılmış, bölümün toplam 560.000 TL tutarındaki giderinin \%82,65'i müşterilere yansıtılmıştır.

\section{BULANIK KÜME TEORİII}

Bulanık küme teorisi uygulamaları ekonomi ve finansta sermaye bütçelemesi, tedarik zinciri planlama, nakit akış analizi ve teknoloji yatırımlarına ilişkin bilgiyi değerlendirmekte kullanılmaktadır. Maliyet analizlerinde, bulanık küme teorisi ilk olarak Nachtmann ve Needy (2001) tarafından FTM sisteminde parametreleri tahmin yöntemi olarak kullanılmıştır. FTM sistemlerinde belirsiz giriş parametresi işlemek için dört model önerilmiştir. Bunlar; i) aralık hesaplama, ii) üçgen dağıtılmış giriş parametreleri ile Monte Carlo simülasyonu, iii) normal dağılım giriş parametreleri ile Monte Carlo simülasyonu ve iv) bulanık küme teorisidir (Chansaad vd., 2012:1952).

Basit ve yalıtılmış doğal çevrelerde çok iyi sonuçlar veren klasik yöntemler, karmaşık, etkileşimli ve sübjektif özellikler taşıyan problemlerin çözümünde her zaman o derece iyi sonuçlar veremeyebilir. Bilim ve teknolojideki gelişmelerin, günümüz yaşamını karmaşık hale getirmesi sonucu, karar süreçleri belirsiz ve incelenmesi zor bir özellik kazanmıştır. Belirsizliği incelemek için kullanılan olasılık teorisinin kavram ve yöntemleri 1960’lı yıllarda tekrar gözden geçirilmiş ve eleştirilmiştir. $\mathrm{Bu}$ eleştiriler doğrultusunda olasıllk teorisinin yerine kullanılabilecek yöntemleri geliştirme çalışmaları yoğunlaşmıştır (Tuş, 2006:1). Bulanık mantık, belirsizlikleri mantıksal ancak kesin olmayan ifadelere ilişkin bilgiyi incelemek değerlendirmek için farklı yöntemler önermektedir (Sarokolaei vd., 2013: 339).

Bulanık mantığın temeli bulanık küme ve alt kümelere dayanır. Klasik yaklaşımda bir varlık, ya kümenin elemanıdır ya da değildir. Matematiksel olarak ifade edildiğinde varlık küme ile olan üyelik ilişkisi bakımından kümenin elemanı olduğunda “1”, kümenin elemanı olmadığı zaman "0” değerini alır. Bulanık mantık klasik küme gösteriminin genişletilmesidir. Bulanık varlık kümesinde her bir varlığın üyelik derecesi vardır. Varlıkların üyelik derecesi, $[0,1]$ aralığında herhangi bir değer olabilir ve üyelik fonksiyonu $\mathrm{f}_{\tilde{\mathrm{A}}}(\mathrm{x})$ ile gösterilir.

Bulanık bir küme, değişik üyelik yani ait olma derecelerine sahip elemanları olan bir küme türüdür. Böyle bir küme, elemanlarının her birine 0 ile 1 arasında üyelik değeri atayabilen bir üyelik fonksiyonu ile karakterize edilebilir. Bulanık kümelerin bu tanımı, bulanık kümelerle ilgili ilk çalışmaları yapan ve bu konunun teorisyeni olarak kabul edilen Lotfi A. Zadeh tarafından 1965 yılında yayınladığı "fuzzy sets" adlı orijinal makalesinde yapılmaktadır. Kümeye dâhil olmayan elemanların üyelik değerleri 0, kümeye tam dâhil olanların üyelik değerleri de 1 olarak atanmaktadır. Kümeye dâhil olup olmadıkları belirsiz olan elemanlara ise belirsizlik durumuna göre 0 ile 1 arasında değerler atanır. Oysa kesin küme teorisinde belirsiz eleman diye bir şey söz konusu değildir. Bir eleman ya kümeye dâhildir ya da tamamı ile kümenin dışındadır. Dolayısıyla kesin kümelerde bir elemanın alabileceği üyelik değeri ya 0 ya da 1 'dir (Altaş, 1999). 
$\mathrm{Bu}$ üyelik derecesi belirsizliği tanımlamaya çalışan bir fonksiyonla ölçülebilir. $\mathrm{Bu}$ fonksiyon bir $\tilde{A}$ bulanık kümesinin elamanlarını [0,1] aralığındaki reel bir değere dönüştürür ve $\mathrm{f}_{\tilde{\mathrm{A}}}(\mathrm{x}) \in[0,1] \mathrm{x}$ boş olmayan bir küme olarak tanımlı varsayılmaktadır. $\mathrm{x}$ 'deki bir bulanık $\tilde{\mathrm{A}}$ kümesi üyelik fonksiyonu $\tilde{\mathrm{A}}: \mathrm{X} \rightarrow[0,1]$ ile özelleştirilmiştir. $\square \mathrm{x} \in \mathrm{x}$ için; $\mathrm{x}$ 'in üyelik derecesi $\mathrm{f}_{\tilde{\mathrm{A}}}(\mathrm{x})$ olarak belirlenmiştir.

Bulanık Küme Teorisinin en büyük katkısı, hatalı bilgi miktarının çokluğunda belirsiz bilgiyi temsil yeteneğidir. Karar vericiler tutarsız ve belirsiz veri olması durumunda bulanık küme teorisinden yararlanabilir. Ayrıca, bulanık verilerin kullanımı yoluyla analitik modellerinde potansiyel riski temsil edebilirler (Nachtmann ve Needy, 2001: 246).

Bulanık sayılar dışbükey, normalleştirilmiş, sınırlı sürekli üyelik fonksiyonu olan ve gerçel sayılarda tanımlanmış bir bulanık küme olarak ifade edilir. Bulanık kümeler üyelik fonksiyonlarıyla tanımlandıkları için bulanık sayılar da kendi üyelik fonksiyonları ile aynı kavramlardır. $\mathrm{Bu}$ nedenle üyelik fonksiyonu çeşidi kadar bulanık sayı çeşidi vardır (Karakaşoğlu, 2008: 85). Üçgen bulanık sayılar, üç reel sayı ile tanımlanmış bulanık sayıların özel bir çeşididir. $\mathrm{f}_{\tilde{\mathrm{A}}}=\left(\mathrm{s}_{\mathrm{i}}, \mathrm{m}_{\mathrm{i}}, \mathrm{l}_{\mathrm{i}}\right)$ şeklinde ifade edilir. $\left(\mathrm{s}_{\mathrm{i}}, \mathrm{m}_{\mathrm{i}}, \mathrm{l}_{\mathrm{i}}\right)$ parametreleri sırasıyla en küçük olası değeri, en olası değeri ve en büyük olası değeri göstermektedir (Ertuğrul ve Karakaşoğlu, 2008: 110, Sarokolaei vd., 2013: 341). $\left(\mathrm{m}_{\mathrm{i}}\right)_{\text {sayıs1 en olası değer }}\left(\mathrm{s}_{\mathrm{i}}\right)_{\text {ve }}\left(\mathrm{l}_{\mathrm{i}}\right)$ parametreleri arasında en uygun değer olarak ele alınacaktır. Bu çalışmada üçgen bulanık sayılardan, sürece dayalı faaliyet tabanlı maliyetlemenin girdi parametrelerini ifade etmekte yararlanılacaktır. Nedeni; üçgen bulanık sayıların, yamuk veya çan gibi diğer bulanık sayıların karmaşık türlerine göre uygulama konusunda doğal olarak daha üstün olmasıdır (Nachtmann ve Needy, 2001: 247, Sarokolaei vd., 2013: 341). Bulanık mantıkta, üçgen sayıları kullanarak süreçlerin iyileştirilmesiyle maliyet verilerinin çıkartılabilmesi ve matematiksel hesaplamaların yapılmasında bu önemli avantaj zorunlu gibi görülmektedir.

İşin yapılmasına ilişkin süre, miktar tahminlerinde öngörü hata katsayısını düşürmek ve süreyi, miktarı tahmin etmekte üçgen bulanık sayıları kullanarak daha doğru hesaplamalar yapmak için genel olarak uzun süreli tahminlerde üçgen bulanık sayılar şeklinde delphi bulanık yöntem kullanılır.

Bulanık delphi yöntemi genellikle geleceğe yönelik uzun dönem tahminlerinde kullanılan bir yöntemdir. Bu yöntemin temeli aşağıdaki gibidir:

Konunun uzmanlarından mümkün olan en küçük olası değeri, en olası değeri ve en büyük olası değeri (üçgen sayılar ile ilgili) tahmin etmeleri istenir.

İstatistiksel olarak hesaplanabilir olan bu soyut bilgilere ilişkin ortalamalar ve sonuçlar diğer uzmanlara kontrol ettirilir.

Tüm uzmanların sonuçları ve yeni tahminleri sınıflandırılır istatistiksel analizleri tekrar kullanmaları için aynı uzmanlara bu veriler tekrar geri gönderilir. 
$\mathrm{Bu}$ işlem karar alıncaya ve uzlaşma gerçekleşinceye kadar devam eder (çoğunlukla 2 veya üç kez tekrarlamak yeterlidir).

Bulanık sistemin genel yapısı aşağıdaki aşamalardan oluşmaktadır.

Bulanıklaştırma $\longrightarrow$ Tümden gelim $\longrightarrow$ Durulaştırma

Bulanıklaştırma işlemi sayısal değişkenleri bulanık yapma işlemidir. Bulanıklaştırma (fuzzy making) sayısal veya kestirilebilir olarak görülen bazı değişkenler, aslında tam anlamıyla sayısal veya kestirilebilir değillerdir. Bazı belirsizlikler taşırlar. Kesinlik, anlamlılık ve doğruluğu azaldıkça belirsizlik artarsa, değişken bulanık olabilmekte ve bir üyelik fonksiyonu ile temsil edilebilmektedir. Bulanık değerlere fonksiyon atamanın birçok yolu mevcuttur. Bu atama işlemleri sezgisel veya algoritmik tabanlı veya mantık işlemleri şeklinde olabilmektedir (Karataş, 2011: 70).

Bulanık çıkarım mekanizması (Tümden gelim), veri tabanındaki girişleri çıkış değişkenlerine bağlayan mantıksal, EĞER - İSE ( IF - THEN), türünde yazılabilen bütün kuralları içermektedir. Bu kuralların yazılmasında sadece girdi verileri ile çıktılar arasında olabilecek tüm aralık bağıntıları kural tabanlı (rule base) olarak düşünülmektedir. Böylece, "her bir kural, girdileri çıktılara mantıksal olarak bağlayan araçlardır" demek mümkündür (Karataş, 2011: 70).

Durulaştırma işlemi bulanık sistemin en son işlemidir. Durulaştırma (defuzzification), bulanık olan bilgilerin kesin sayılar haline dönüştürülüp kesin sonuçlar elde edilmesi için yapılan işlemlerin tümüdür (Karataş, 2011: 71).

\subsection{Bulanık Sayılar}

Bulanık sayılar dışbükey, normalleştirilmiş, sınırlı sürekli üyelik fonksiyonu olan ve gerçel sayılarda tanımlanmış bir bulanık kümedir. Bulanık sayı, gerçel $r$ sayısının genelleştirilmiş şekli olan bulanık bir $\tilde{A}$ niceliğidir. Burada $\tilde{A}(x), \tilde{A}$ (x)'in r'ye ne kadar yaklaşık değerler aldığının bir ölçüsüdür. Bu durumda A (r) = 1 olacaktır (Karakaşoğlu, 2008: 85).

Ekseriya, gerçek dünyada karşılaşılan nesne sınıflarının üyeliklerine ilişkin kesin olarak tanımlanmış ölçüler bulunmamaktadır (Zadeh, 1965: 338). Sayısal bilgilerin hassas bir şekilde tanımlanamadığı durumlarda; “yaklaşık 60", “0’a yakın”, "5.000'den büyük” şeklinde ifadeler günlük hayatta sık sık kullanılmaktadır. Bunlar bulanık sayılara birer örnektir. Bulanık sayı olağan sayılara göre belirsiz bir değerdir. Bulanık alt-kümeler teorisi kullanarak, söz konusu bulanık sayılar reel sayılar kümesinin bir bulanık alt-kümesi olarak tanımlanabilir.

İşlem kolaylığı sağlaması ve sezgisel olarak oluşturulabilmesi nedeniyle en çok kullanılan bulanık sayı türünün üçgen bulanık sayılar olduğu ifade edilmektedir. Bununla birlikte işlem verimliliği ve veri kazanım kolaylığı nedeniyle yamuk bulanık sayıların da sıklıkla kullanıldığı belirtilmektedir (Ecer, 2007: 163). Konusuna göre değişik bulanık sayılar 
kullanmakla birlikte, genel olarak uygulamalarda kullanılan üçgen ve yamuk olmak üzere iki tane bulanık sayı söz konusudur (Karakaşoğlu, 2008: 85).

\section{2. Üçgen Bulanık Sayılar}

Üçgen bulanık sayılar, üç tane gerçek sayılarla tanımlanmış bulanık sayıların özel bir çeşididir. $\left(\mathrm{s}_{\mathrm{i}}, \mathrm{m}_{\mathrm{i}}, \mathrm{l}_{\mathrm{i}}\right)$ şeklinde ifade edilir. $\mathrm{s}_{\mathrm{i}}, \mathrm{m}_{\mathrm{i}}$ ve $\mathrm{l}_{\mathrm{i}}$ parametreleri sırasıyla en küçük olası değeri, en olası değeri ve en büyük olası değeri göstermektedir. Üçgen bulanık $\widetilde{A}$ sayısının grafik gösterimi Şekil 2'de verilmiştir (Karakaşoğlu, 2008: 85, Chansaad vd., 2012: 1952, Mortaji vd., 2013: 65).

Şekil 2: Üçgen bulanık sayı, $\tilde{A}$

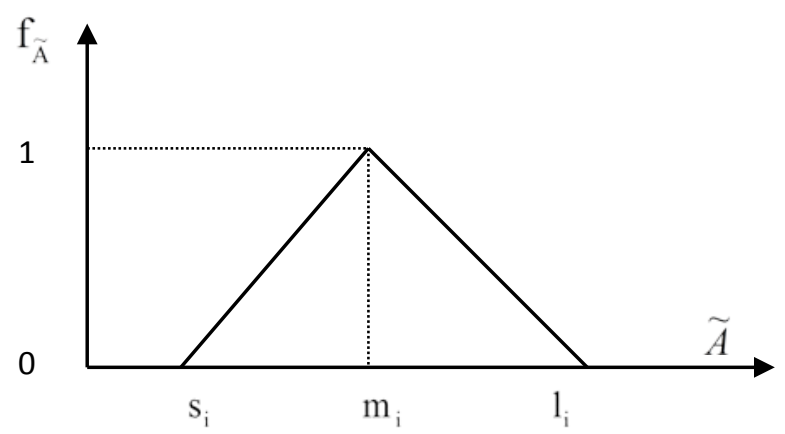

$\mathrm{s}_{\mathrm{i}}$ ve $\mathrm{l}_{\mathrm{i}}$; bulanık küme desteğinin alt ve üst sınır değerleri ve $\mathrm{m}_{\mathrm{i}}$, tam üyelikli tek sayı olmak üzere üçgen bulanık sayının üyelik fonksiyonu şu şekilde tanımlanır:

$$
\mathrm{f}_{\tilde{\mathrm{A}}}= \begin{cases}0, & \mathrm{x}<\mathrm{s}_{\mathrm{i}}, \\ \left(\mathrm{x}-\mathrm{s}_{\mathrm{i}}\right) /\left(\mathrm{m}_{\mathrm{i}}-\mathrm{s}_{\mathrm{i}}\right), & \mathrm{s}_{\mathrm{i}} \leq \mathrm{x} \leq \mathrm{m}_{\mathrm{i}}, \\ \left(\mathrm{l}_{\mathrm{i}}-\mathrm{x}\right) /\left(\mathrm{l}_{\mathrm{i}}-\mathrm{m}_{\mathrm{i}}\right), & \mathrm{m}_{\mathrm{i}} \leq \mathrm{x} \leq \mathrm{l}_{\mathrm{i}}, \\ 0, & \mathrm{x}>\mathrm{l}\end{cases}
$$

Üçgen bulanık sayılardan işletme yönetimince belirsizlik altında yönetsel karar vermede yararlanılabilir. Ayrıca, az bilgi olması durumunda da kolaylıkla oluşturulabilirler (Karakaşoğlu, 2008: 86).

\section{3. Üçgen Bulanık Sayılarda İşlemler}

Üçgen bulanık sayılarla işlem yaparken göz önünde bulundurulması gereken hususlar:

- $\quad$ Üçgen bulanık sayıların toplama ve çıkarma işlemleri sonucu yine bir üçgen bulanık sayı çıkar.

- $\quad$ Üçgen bulanık sayılarla çarpma, bölme ve ters işlem, sonuç olarak her zaman üçgen bulanık sayı vermez.

- $\quad$ Üçgen bulanık sayılarla maksimum veya minimum işlemleri de sonuç olarak her zaman üçgen bulanık sayı vermez. 
Ancak, bu işlemlerin sonuçları, yaklaşık üçgen bulanık sayı olarak kabul edilebilir.

İki pozitif bulanık sayı A ve $\mathrm{B}, \tilde{\mathrm{A}}=\left(\mathrm{s}_{1}, \mathrm{~m}_{1}, \mathrm{l}_{1}\right), \widetilde{\mathrm{B}}=\left(\mathrm{s}_{2}, \mathrm{~m}_{2}, \mathrm{l}_{2}\right)$ şeklinde tanımlanacak olursa, “ $\oplus$ ” bulanık toplama işlemini, “ $\Theta$ ” bulanık çıkarma işlemini, “ $\otimes$ ” bulanık çarpma işlemini ve " $\phi$ ” bulanık bölme işlemini göstermek üzere aşağıdaki gibidir.

- Toplama işlemi:

$\tilde{\mathrm{A}} \oplus \tilde{\mathrm{B}}=\left(\mathrm{s}_{1}, \mathrm{~m}_{1}, \mathrm{l}_{1}\right) \oplus\left(\mathrm{s}_{2}, \mathrm{~m}_{2}, \mathrm{l}_{2}\right)=\left(\mathrm{s}_{1}+\mathrm{s}_{2}, \mathrm{~m}_{1}+\mathrm{m}_{2}, \mathrm{l}_{1}+\mathrm{l}_{2}\right)$

- Çıkarma işlemi:

$\tilde{\mathrm{A}} \Theta \tilde{B}=\left(\mathrm{s}_{1}, \mathrm{~m}_{1}, \mathrm{l}_{1}\right) \Theta\left(\mathrm{s}_{2}, \mathrm{~m}_{2}, \mathrm{l}_{2}\right)=\left(\mathrm{s}_{1}-\mathrm{s}_{2}, \mathrm{~m}_{1}-\mathrm{m}_{2}, \mathrm{l}_{1}-\mathrm{l}_{2}\right)$

- Çarpma işlemi:

$\widetilde{A} \otimes \widetilde{B}=\left(s_{1}, m_{1}, l_{1}\right) \otimes\left(s_{2}, m_{2}, l_{2}\right)=\left(s_{1} \cdot s_{2}, m_{1} \cdot m_{2}, l_{1} \cdot l_{2}\right)$

- Sabit sayıyla çarpma işlemi:

$\widetilde{\mathrm{A}} \otimes \mathrm{k}=\left(\mathrm{s}_{1}, \mathrm{~m}_{1}, \mathrm{l}_{1}\right) \otimes \mathrm{k}=\left(\mathrm{s}_{1} \cdot \mathrm{k}, \mathrm{m}_{1} \cdot \mathrm{k}, \mathrm{l}_{1} \cdot \mathrm{k}\right)$

- Bölme işlemi:

$\tilde{\mathrm{A}} \phi \tilde{\mathrm{B}}=\left(\mathrm{s}_{1}, \mathrm{~m}_{1}, \mathrm{l}_{1}\right) \phi\left(\mathrm{s}_{2}, \mathrm{~m}_{2}, \mathrm{l}_{2}\right)=\left(\mathrm{s}_{1} / \mathrm{s}_{2}, \mathrm{~m}_{1} / \mathrm{m}_{2}, \mathrm{l}_{1} / \mathrm{l}_{2}\right)$

- Ters işlem:

$\tilde{\mathrm{A}}^{-1}=\left(\mathrm{s}_{1}, \mathrm{~m}_{1}, \mathrm{l}_{1}\right)^{-1} \approx\left(1 / \mathrm{l}_{1}, 1 / \mathrm{m}_{1}, 1 / \mathrm{s}_{1}\right)$

4. BULANIK SÜRECE DAYALI FAALIYYET TABANLI MALIYYETLEME

Kaplan ve Anderson'un (2004) sürece dayalı faaliyet tabanlı maliyetlemesinde "pratik kapasite” ve "her faaliyet için gerekli zaman”, önemli iki kritik parametre olduğu halde bu parametrelere nasıl tahmin yapılacağına ilişkin açık bilimsel yönergeden bahsedilmemektedir. Ayrıca bu tahminlerin yanlış yapılması durumunda, mal ve hizmetlerin maliyetlerine yapılan atamalar gibi sonuçlar üzerinde, sapmanın miktarının artması şeklinde önemli etkilere neden olmaktadır. Bu sapmalar yöneticilerin uygun olmayan kararlar almalarına yol açabilecektir (Mortaji vd., 2013: 66).

Sürece Dayalı Faaliyet Tabanlı Maliyetlemede yönetim; örneğin depodan hammaddenin taşınması, iş emirlerinin düzenlenmesi ve mamullerin depoda yerlerine yerleştirilmesi gibi herhangi bir faaliyeti gerçekleştirmek için gereken süreyi öngörür. Yönetim bu tahminlerinin gerçek faaliyet ve işlemleri yansıtacak şekilde olmasına dikkat etmelidir.

$\mathrm{Bu}$ tahminler çoğunlukla Sürece Dayalı Faaliyet Tabanlı Maliyetleme sisteminin doğruluğu ve güvencesine ilişkin eksiklikleri oluşturmaktadır. Bulanık mantık, sürece dayalı faaliyet tabanlı maliyetlemedeki veri güvencesinin eksikliğinde veriyi değiştirmek için sürece dayalı faaliyet tabanlı maliyetleme sistemi ile karşılaştırıldığında bulanık sürece dayalı 
faaliyet tabanlı maliyetleme daha doğru ve uygun sonuçlar üretebilen en etkili yöntemlerden biridir (Sarokolaei vd., 2013: 341). Bulanık sürece dayalı faaliyet tabanlı maliyetlemede, yönetim her faaliyetin uygulanmasında gerekli süreyi tahmin etmekte delphi bulanık formunda üçgen bulanık sayılar kullanır. Yönetim; mümkün olan en küçük değer, en olası değer ve en büyük değer şeklinde üç sayı içeren bir aralık içinde pratik kapasite tahminleri ile bir iş emrini yapmak gibi her faaliyeti gerçekleştirmek için gerekli tahminleri öngörür. (Sarokolaei vd., 2013: 341).

Delphi bulanık formunda üçgen bulanık sayıları kullanmanın en önemli avantajı, en muhtemel olası değer şeklinde sürece dayalı faaliyet tabanlı maliyetleme standart sistemini ve her bölümdeki uzmanların yeterliliklerine güvenerek sürece dayalı faaliyet tabanlı maliyetleme sisteminde maliyet analizleri yapılabilecek olmasıdır. Bu şekilde sağlanan bulanık veri girişi, bilgilerin hiçbirinin kaybolmadan SDFTM sisteminden standartlaştırılmış ilave bilgiler oluşturulmasına ve güvence kazanmasına neden olacaktır. Böylece, bulanık mantık kullanarak doğal yanlışlıkla ilgili öğeleri dikkate alabilir ve verilerin uygunsuzluğu ve sürece dayalı faaliyet tabanlı maliyetlemenin güvence eksikliğinin üstesinden gelerek, güvencesi daha yüksek sonuçlar üretir ve maliyet hesaplamaları yapılabilir (Sarokolaei vd., 2013: 341).

Daha iyi karar verebilmek için üçgen bulanık sayıların durulaştırılması gerekir. Mevcut durulaştırma tekniklerinden bir kısmı; en büyük üyelik ilkesi yöntemi, centroid yöntemi, ağırlıklı ortalama yöntemi, ortalama en büyük üyelik yöntemi, toplamların merkezi yöntemi, en büyük alan merkezi yöntemi şeklinde sıralanabilir (Chansaad vd., 2012: 1952, Chou ve Chang, 2008: 2246). Durulaştırma yöntemlerinden toplamların merkezi yöntemi durulaştırma yöntemi, en hızlı yöntem olduğundan çalışmada bu yöntem kullanılmıştır. Yöntemde cebirsel toplamlar kullanılır. Durulaştırma ile elde edilecek sayılarla pratik kapasite ve her faaliyetin süresi hesaplanacak ve bu şekilde bulunan rakamlar bulanık sürece dayalı faaliyet tabanlı maliyetleme olarak adlandırılacaktır. Sistemin aşamaları aşağıda açıklanacaktır:

a) Bulanık sürece dayalı faaliyet tabanlı maliyetlemede pratik kapasiteyi belirlemek için bulanıklaştırılmış rakamlar durulaştırılır.

Tablo 3: Bölümün Durulaştırılmış Pratik Kapasitesi

\begin{tabular}{|c|c|c|c|}
\hline $\begin{array}{c}\text { En küçük olası pratik } \\
\text { kapasite }\end{array}$ & En olası pratik kapasite & $\begin{array}{c}\text { En büyük olas1 pratik } \\
\text { kapasite }\end{array}$ & $\begin{array}{c}\text { Durulaştırılmış pratik } \\
\text { kapasite }\end{array}$ \\
\hline$\% 84$ & $\% 90$ & $\% 93$ & $\% 89$ \\
\hline
\end{tabular}

Her faaliyetin maliyet oranı; $13.000 * \% 89=11.570 * 60=694.200$ dakika

$560.000 \mathrm{TL} / 694.200=0,8066 \mathrm{TL} / \mathrm{dk}$.

b) Siparişlerin alınması faaliyetini yapmak için gerekli zamanı belirlemek için; 
Tablo 4: Siparişlerin Alınması Faaliyeti İçin Gerekli Zaman Tahminleri

\begin{tabular}{|c|c|c|c|c|l|}
\hline $\mathrm{E}_{\mathrm{i}}$ & $\mathrm{A}_{\mathrm{i}}$ (ilk sipariş) & $\begin{array}{c}\text { En küçük } \mathrm{a}_{\mathrm{s}} \\
\text { tahmini }\end{array}$ & $\begin{array}{c}\text { En olası } \mathrm{a}_{\mathrm{m}} \\
\text { tahmini }\end{array}$ & $\begin{array}{c}\text { En büyük } \mathrm{a}_{1} \\
\text { tahmini }\end{array}$ & \multicolumn{1}{|c|}{ Süreç } \\
\hline $\mathrm{E}_{1}$ & $\mathrm{~A}_{1}$ & 39 & 40 & 44 & Siparişlerin alınmas1 \\
\hline $\mathrm{E}_{2}$ & $\mathrm{~A}_{2}$ & 37 & 39 & 43 & Siparişlerin alınmas1 \\
\hline $\mathrm{E}_{3}$ & $\mathrm{~A}_{3}$ & 38 & 41 & 45 & Siparişlerin alınmas1 \\
\hline $\mathrm{E}_{4}$ & $\mathrm{~A}_{4}$ & 41 & 43 & 46 & Sipariş̧lerin alınmas1 \\
\hline $\mathrm{E}_{5}$ & $\mathrm{~A}_{5}$ & 37 & 40 & 44 & Sipariş̧lerin alınmas1 \\
\hline
\end{tabular}

Öncelikle karar verici veya uzmanlardan en küçük, en olası ve en büyük tahminde bulunmaları istenir. Bu tahminler bulanık üçgen sayılar şeklinde gösterilir.

$\mathrm{E}_{\mathrm{i}}:$ Karar verici veya uzman, $\mathrm{i}=1,2, \ldots ., \mathrm{n}$

$\mathrm{n}$ karar verici veya uzman sayısını göstermek üzere;

Toplamlar $=\mathrm{i}=1 \quad \mathrm{a}_{\mathrm{s}_{\mathrm{i}}}=192 \sum_{\mathrm{i}=1}^{\mathrm{n}} \mathrm{a}_{\mathrm{m}_{\mathrm{i}}}=203 \sum_{\mathrm{i}=1}^{\mathrm{n}} \mathrm{a}_{\mathrm{l}_{\mathrm{i}}}=222$

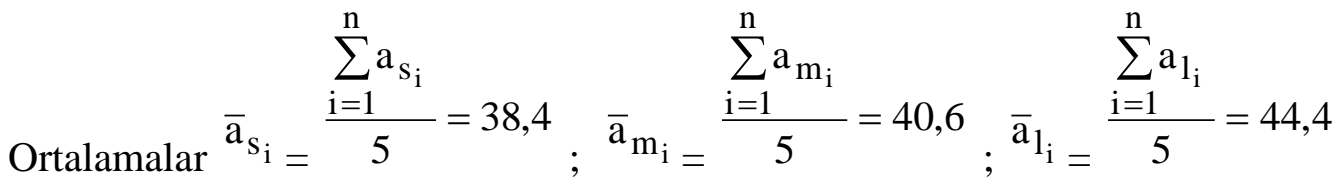

Toplamlar ve ortalamalar hesaplandıktan sonra karar verici veya uzmanların tahminlerinin ortalamalardan sapmaları hesaplanır.

Tablo 5: Zaman Tahminleri Sapma Tablosu

\begin{tabular}{|c|c|c|c|}
\hline & $\overline{\mathrm{a}}_{\mathrm{s}}-\mathrm{a}_{\mathrm{s}}$ & $\overline{\mathrm{a}}_{\mathrm{m}}-\mathrm{a}_{\mathrm{m}}$ & $\overline{\mathrm{a}}_{1}-\mathrm{a}_{1}$ \\
\hline $\mathrm{E}_{1}$ & $38,4-39=-0,6$ & $40,6-40=0,6$ & $44,4-44=0,4$ \\
\hline $\mathrm{E}_{2}$ & $38,4-37=1,4$ & $40,6-39=1,6$ & $44,4-43=1,4$ \\
\hline $\mathrm{E}_{3}$ & $38,4-38=0,4$ & $40,6-41=-0,4$ & $44,4-45=-0,6$ \\
\hline $\mathrm{E}_{4}$ & $38,4-41=-2,6$ & $40,6-43=2,4$ & $44,4-46=-1,6$ \\
\hline $\mathrm{E}_{5}$ & $38,4-37=1,4$ & $40,6-40=0,6$ & $44,4-44=0,4$ \\
\hline
\end{tabular}

Yönetimin bu ortalamalar ( $\overline{\mathrm{a}}_{\mathrm{s}} 38,4 ; \overline{\mathrm{a}}_{\mathrm{m}} 40,6$ ve $\left.\overline{\mathrm{a}}_{1} 44,4\right)$ üzerinde anlaştığı varsayılsın. Bu sapmalar yeniden incelenmesi için tekrar karar verici veya uzmanlara gönderilir. Bunun sonucu karar verici veya uzmanların önerdiği üçgen sayılar şöyle olur; 
Tablo 6: Siparişlerin Alınması Faaliyeti İçin Gerekli Zaman Tahminleri

\begin{tabular}{|c|c|c|c|c|l|}
\hline $\mathrm{E}_{\mathrm{i}}$ & $\mathrm{B}_{\mathrm{i}}$ (ilk sipariş) & $\begin{array}{c}\text { En küçük } \mathrm{b}_{\mathrm{s}} \\
\text { tahmini }\end{array}$ & $\begin{array}{c}\text { En olası } \mathrm{b}_{\mathrm{m}} \\
\text { tahmini }\end{array}$ & $\begin{array}{c}\text { En büyük } \mathrm{b}_{1} \\
\text { tahmini }\end{array}$ & \multicolumn{1}{|c|}{ Süreç } \\
\hline $\mathrm{E}_{1}$ & $\mathrm{~B}_{1}$ & 39 & 40 & 43 & Siparişlerin alınmas1 \\
\hline $\mathrm{E}_{2}$ & $\mathrm{~B}_{2}$ & 38 & 40 & 42 & Siparişlerin alınmas1 \\
\hline $\mathrm{E}_{3}$ & $\mathrm{~B}_{3}$ & 38 & 40 & 43 & Siparişlerin alınmas1 \\
\hline $\mathrm{E}_{4}$ & $\mathrm{~B}_{4}$ & 40 & 42 & 44 & Siparişlerin alınmas1 \\
\hline $\mathrm{E}_{5}$ & $\mathrm{~B}_{5}$ & 39 & 41 & 43 & Siparişlerin alınmas1 \\
\hline
\end{tabular}

Toplamlar $=\sum_{\mathrm{i}=1}^{\mathrm{n}} \mathrm{b}_{\mathrm{s}_{\mathrm{i}}}=194 ; \sum_{\mathrm{i}=1}^{\mathrm{n}} \mathrm{b}_{\mathrm{m}_{\mathrm{i}}}=203 ; \sum_{\mathrm{i}=1}^{\mathrm{n}} \mathrm{b}_{\mathrm{l}_{\mathrm{i}}}=215$

Ortalamalar $\bar{b}_{s_{i}}=\frac{\sum_{i=1}^{n} b_{s_{i}}}{5}=38,8 ; \bar{b}_{m_{i}}=\frac{\sum_{i=1}^{n} b_{m_{i}}}{5}=40,6 ; \bar{b}_{l_{i}}=\frac{\sum_{i=1}^{n} b_{l_{i}}}{5}=43$

Elde edilen her iki ortalama birbirine yakın olduğu için yönetici, belirli bir kanaate ulaşmıştır. Dolayısıyla bulanık delphi işlemini durdurur ve ( $\overline{\mathrm{b}}_{\mathrm{s}} 38,8 ; \overline{\mathrm{b}}_{\mathrm{m}} 40,6 ; \overline{\mathrm{b}}_{1}$ 43) bulanık sayıları karar verici veya uzmanların fikirlerinin ortak sonucu olarak kabul eder.

Şikayetlerin işlenmesi faaliyetini yapmak için gerekli zamanı belirlemek amacıyla;

Tablo 7: Şikâyetlerin İşlenmesi Faaliyeti İçin Gerekli Zaman Tahminleri

\begin{tabular}{|c|c|c|c|c|l|}
\hline $\mathrm{E}_{\mathrm{i}}$ & $\begin{array}{c}\mathrm{A}_{\mathrm{i}} \text { (ilk } \\
\text { sipariş) }\end{array}$ & $\begin{array}{c}\text { En küçük } \mathrm{a}_{\mathrm{s}} \\
\text { tahmini }\end{array}$ & $\begin{array}{c}\text { En olası } \mathrm{a}_{\mathrm{m}} \\
\text { tahmini }\end{array}$ & $\begin{array}{c}\text { En büyük } \mathrm{a}_{1} \\
\text { tahmini }\end{array}$ & \multicolumn{1}{|c|}{ Süreç } \\
\hline $\mathrm{E}_{1}$ & $\mathrm{~A}_{1}$ & 215 & 220 & 242 & Şikâyetlerin işlenmesi \\
\hline $\mathrm{E}_{2}$ & $\mathrm{~A}_{2}$ & 204 & 215 & 237 & Şikâyetlerin işlenmesi \\
\hline $\mathrm{E}_{3}$ & $\mathrm{~A}_{3}$ & 210 & 226 & 248 & Şikâyetlerin işlenmesi \\
\hline $\mathrm{E}_{4}$ & $\mathrm{~A}_{4}$ & 226 & 237 & 253 & Şikâyetlerin işlenmesi \\
\hline $\mathrm{E}_{5}$ & $\mathrm{~A}_{5}$ & 210 & 222 & 240 & Şikâyetlerin işlenmesi \\
\hline
\end{tabular}

Toplamlar $=\sum_{\mathrm{i}=1}^{\mathrm{n}} \mathrm{a}_{\mathrm{s}_{\mathrm{i}}}=1.065 ; \sum_{\mathrm{i}=1}^{\mathrm{n}} \mathrm{a}_{\mathrm{m}_{\mathrm{i}}}=1.120 ; \sum_{\mathrm{i}=1}^{\mathrm{n}} \mathrm{a}_{\mathrm{l}_{\mathrm{i}}}=1.220$

Ortalamalar $\overline{\mathrm{a}}_{\mathrm{s}_{\mathrm{i}}}=\frac{\sum_{\mathrm{i}=1}^{\mathrm{n}} \mathrm{a}_{\mathrm{s}_{\mathrm{i}}}}{5}=213 ; \overline{\mathrm{a}}_{\mathrm{m}_{\mathrm{i}}}=\frac{\sum_{\mathrm{i}=1}^{\mathrm{n}} \mathrm{a}_{\mathrm{m}_{\mathrm{i}}}}{5}=224 ; \overline{\mathrm{a}}_{\mathrm{l}_{\mathrm{i}}}=\frac{\sum_{\mathrm{i}=1}^{\mathrm{n}} \mathrm{a}_{\mathrm{l}_{\mathrm{i}}}}{5}=244$ 
Sonra karar verici veya uzmanların tahinlerinin ortalamalardan sapmaları hesaplanır.

Tablo 8: Zaman Tahminleri Sapma Tablosu

\begin{tabular}{|c|c|c|c|}
\hline$E_{i}$ & $\bar{a}_{s}-a_{s}$ & $\bar{a}_{m}-a_{m}$ & $\bar{a}_{1}-a_{1}$ \\
\hline$E_{1}$ & $213-215=-2$ & $224-220=4$ & $244-242=2$ \\
\hline$E_{2}$ & $213-204=9$ & $224-215=9$ & $244-237=7$ \\
\hline$E_{3}$ & $213-210=3$ & $224-226=-2$ & $244-248=-4$ \\
\hline$E_{4}$ & $213-226=-13$ & $224-237=-13$ & $244-253=-9$ \\
\hline$E_{5}$ & $213-210=3$ & $224-222=2$ & $244-240=4$ \\
\hline
\end{tabular}

Yönetimin bu ortalamalar ( ${ }^{\overline{\mathrm{s}}_{\mathrm{s}}} 213 ; \overline{\mathrm{a}}_{\mathrm{m}} 224$ ve ${ }^{\overline{\mathrm{a}}_{1}}$ 244) üzerinde anlaştı̆̆ varsayılsın. Bu sapmalar yeniden incelenmesi için tekrar karar verici veya uzmanlara gönderilir. Bunun sonucu karar verici veya uzmanların önerdiği $\mathrm{B}_{\mathrm{i}}$ üçgen sayılar;

Tablo 9: Şikâyetlerin İşlenmesi Faaliyeti İçin Gerekli Zaman Tahminleri

\begin{tabular}{|c|c|c|c|c|l|}
\hline $\mathrm{E}_{\mathrm{i}}$ & $\begin{array}{c}\mathrm{B}_{\mathrm{i}} \text { (ilk } \\
\text { sipariş) }\end{array}$ & $\begin{array}{c}\text { En küçük } \mathrm{b}_{\mathrm{s}} \\
\text { tahmini }\end{array}$ & $\begin{array}{c}\text { En olası } \mathrm{b}_{\mathrm{m}} \\
\text { tahmini }\end{array}$ & $\begin{array}{c}\text { En büyük } \mathrm{b}_{\mathrm{l}} \\
\text { tahmini }\end{array}$ & Süreç \\
\hline $\mathrm{E}_{1}$ & $\mathrm{~B}_{1}$ & 215 & 220 & 237 & Şikâyetlerin işlenmesi \\
\hline $\mathrm{E}_{2}$ & $\mathrm{~B}_{2}$ & 209 & 220 & 231 & Şikâyetlerin işlenmesi \\
\hline $\mathrm{E}_{3}$ & $\mathrm{~B}_{3}$ & 209 & 223 & 237 & Şikâyetlerin işlenmesi \\
\hline $\mathrm{E}_{4}$ & $\mathrm{~B}_{4}$ & 220 & 230 & 253 & Şikâyetlerin işlenmesi \\
\hline $\mathrm{E}_{5}$ & $\mathrm{~B}_{5}$ & 215 & 222 & 237 & Şikâyetlerin işlenmesi \\
\hline
\end{tabular}

Toplamlar $=\sum_{\mathrm{i}=1}^{\mathrm{n}} \mathrm{b}_{\mathrm{s}_{\mathrm{i}}}=1.068 ; \sum_{\mathrm{i}=1}^{\mathrm{n}} \mathrm{b}_{\mathrm{m}_{\mathrm{i}}}=1.115 ; \sum_{\mathrm{i}=1}^{\mathrm{n}} \mathrm{b}_{\mathrm{l}_{\mathrm{i}}}=1.195$

Ortalamalar $\bar{b}_{s_{i}}=\frac{\sum_{i=1}^{n} b_{s_{i}}}{5}=213,6 ; \bar{b}_{m_{i}}=\frac{\sum_{i=1}^{n} b_{m_{i}}}{5}=223 ; \bar{b}_{l_{i}}=\frac{\sum_{i=1}^{n} b_{l_{i}}}{5}=239$

Elde edilen her iki ortalama birbirine yakın olduğu için yönetici, belirli bir kanaate ulaşmıştır. Dolayısıyla bulanık delphi işlemini durdurur ve $\left(\overline{\mathrm{b}}_{\mathrm{s}} 213,6 ; \overline{\mathrm{b}}_{\mathrm{m}} 223 ; \overline{\mathrm{b}}_{1}\right.$ 239) bulanık sayıları karar verici veya uzmanların fikirlerinin ortak sonucu olarak kabul eder. Aynı işlemlerin müşteri kredibilite kontrolü için yapıldığını varsayalım. 
Tablo 10: Bölümün Bulanık Sürece Dayalı Faaliyet Tabanlı Faaliyet Zamanları

\begin{tabular}{|l|c|c|c|c|}
\hline Faaliyet & $\begin{array}{c}\text { Her bir ürün için } \\
\text { gerekli en uzun } \\
\text { süre (dakika) }\end{array}$ & $\begin{array}{c}\text { Her bir ürün için } \\
\text { gerekli en olas } \\
\text { süre (dakika) }\end{array}$ & $\begin{array}{c}\text { Her bir ürün için } \\
\text { gerekli en az süre } \\
\text { (dakika) }\end{array}$ & $\begin{array}{c}\text { Her bir ürün için } \\
\text { gereken durulaştırma } \\
\text { sonras1 süre (dakika) }\end{array}$ \\
\hline $\begin{array}{l}\text { Siparişlerin } \\
\text { alınmas1 }\end{array}$ & 43,0 & 40,6 & 38,8 & 40,8 \\
\hline $\begin{array}{l}\text { Sikâyetlerin } \\
\text { işlenmesi }\end{array}$ & 239 & 223 & 213,6 & 225,2 \\
\hline $\begin{array}{l}\text { Müşteri kredibilite } \\
\text { Kontrol }\end{array}$ & 266 & 250 & 244 & 253,3 \\
\hline
\end{tabular}

Tablo 11: Bölümün Bulanık Sürece Dayalı Faaliyet Tabanlı Faaliyet ve Maliyetleri

\begin{tabular}{|l|c|c|c|c|}
\hline Faaliyet & $\begin{array}{c}\text { Her bir ürün için } \\
\text { gerekli süre (dakika) }\end{array}$ & $\begin{array}{c}\text { Yükleme ölçüsü } \\
\text { hacmi (miktar) }\end{array}$ & $\begin{array}{c}\text { Tüketilen toplam } \\
\text { süre (dakika) }\end{array}$ & $\begin{array}{c}\text { Toplam faaliyet } \\
\text { maliyeti (TL) }\end{array}$ \\
\hline $\begin{array}{l}\text { Siparişlerin } \\
\text { alınmas1 }\end{array}$ & 40,8 & 9.800 & 399.840 & 322.511 \\
\hline $\begin{array}{l}\text { Şikâyetlerin } \\
\text { işlenmesi }\end{array}$ & 225,2 & 280 & 63.056 & 50.861 \\
\hline $\begin{array}{l}\text { Müşteri kredibilite } \\
\text { Kontrol }\end{array}$ & 253,3 & 500 & 126.650 & 102.156 \\
\hline $\begin{array}{l}\text { Kullanılan } \\
\text { kapasite }\end{array}$ & & & 589.546 & 475.528 \\
\hline $\begin{array}{l}\text { Kullanılmayan } \\
\text { kapasite }\end{array}$ & & & 110.454 & 84.472 \\
\hline Toplam & & & 700.000 & 560.000 \\
\hline
\end{tabular}

Tablo 11'den görüleceği gibi faaliyet döneminde bölümün pratik kapasitesinden \%84,22 (589.546/700.000) oranında yararlanılmış, bölümün toplam 560.000 TL tutarındaki giderinin \%84,92'si müşterilere yansıtılmıştır. Bu rakamlar bilginin kesin olmaması durumlarında bulanık SDFTM sisteminden makul maliyet verileri sonucuna ulaşmaya yardımcı olacaktır.

\section{SONUÇ}

$\mathrm{Bu}$ çalışmada, sürece dayalı faaliyet tabanlı maliyet sistemindeki mutlak verinin eksikliğinden kaynaklanabilecek yanlışlıkları telafi için bulanık mantık üçgen sayılar kullanılarak katsayıların hataların en aza indirilme sürecini ifade eden bulanık sürece dayalı faaliyet tabanlı maliyet sistemi anlatılmıştır. Sürece dayalı faaliyet tabanlı maliyet sistemi büyük ölçüde zaman tahminlerine dayanır ve esasen soyut veya sübjektiftir. Sürece dayalı faaliyet tabanlı maliyet sisteminde faaliyetlerin zamanına ilişkin tahminlerde hatalar oluşursa bu sistem hasar verici etkilere neden olabilir. Bu nedenle, daha yüksek güvence düzeylerinde kararlar gerekir ki, doğru zaman tahminleri ile yöneticilere hataları en aza indirmek için bulanık mantık kullanmaları önerilmektedir. 
Belirsiz bir ortamda veri değişimi olduğunda SDFTM sistemi sadece ortalama bilgilere dayanır. Bulanık SDFTM sistemi üyelik fonksiyonu sayesinde değişim durumlarında ağırlıkları dağıtarak maliyet hesaplamalarında tüm olası, en küçük, en olası ve en büyük vakaları dikkate alır. Bulanık SDFTM sistemi veri eksikliğinde de makul maliyet tahminleri yapmakta yarar sağlayabilir.

Sürece dayalı faaliyet tabanlı maliyetleme ile faaliyet döneminde bölümün pratik kapasitesinden \%82,65 (578.600/700.000) oranında yararlanılmış, bölümün toplam 560.000 TL tutarındaki giderinin \%82,65'i müşterilere yansıtılmıştır (Tablo 2). Buna karşılık, bulanık sürece dayalı faaliyet tabanlı maliyetleme ile faaliyet döneminde bölümün pratik kapasitesinden \%84,22 (589.546/700.000) oranında yararlanılmış ve dolayısıyla bölümün toplam 560.000 TL tutarındaki giderinin \%84,92'si müşterilere yansıtılmıştır (Tablo 11).

Daha güvenilir maliyet bilgisi sağlamak amacıyla kullanılabilecek olan bulanık sürece dayalı faaliyet tabanlı maliyetleme, belirsizliğin oldukça yüksek olduğu iş çevrelerinde faaliyet gösteren ve doğru maliyet tahminlerine ihtiyaç duyan işletme yöneticilerine karşılaştıkları karar verme problemlerine çözüm bulabilmek için uygulanabilir bir maliyet hesaplama yaklaşımı olabilir.

\section{KAYNAKLAR}

Akgün, Ali İhsan (2012), “TMS-2 Stoklar Standardı Kapsamında Tam Maliyet ve Normal Maliyete Göre Düzenlenen Gelir Tabloları Karşılaştırması”, Süleyman Demirel Üniversitesi İktisadi ve İdari Bilimler Fakültesi Dergisi, Cilt 17, Sayı 2, ss. 229-246.

Altaş, İsmail H. (1999), "Bulanık Mantık: Bulanıklılık Kavramı”, Enerji, Elektrik, Elektromekanik-3e, Bileşim yayıncılık A.Ş., İstanbul, Temmuz, Sayı 62, ss. 80-85.

Bruns, William J. - Kaplan, Robert S. (1987), Accounting and Management: A Field Study Perspective, Harvard Bussiness School Press. Boston, Massachusetts.

Büyükmirza, H. Kamil (2009), Maliyet ve Yönetim Muhasebesi, 15. Bask1, Gazi Kitabevi, Ankara.

Chansaad, Annaruemon Phoonsiri - Rattanamanee, Wanida - Chaiprapat, Supapan Yenradee, Pisal (2012), “A Fuzzy Time-Driven Activity-Based Costing Model İn An Uncertain Manufacturing Environment”, Proceedings of the Asia Pacific Industrial Engineering \& Management Systems Conference, pp. 1949-1959.

Chou, Shuo-Yan - Chang, Yao-Hui (2008), “A Decision Support System For Supplier Selection Based On A Strategy-Aligned Fuzzy SMART Approach”, Expert Systems With Applications, Vol. 34, No. 4, pp. 2241-2253.

Cooper, Robin - Kaplan, Robert S. (1988), "Measure Costs Right: Make The Right Decisions”, Harvard Business Review, Vol.66, No.5, pp. 96-103.

Cooper, Robin - Kaplan, Robert S. (1991), "Profit Priorities From Activity-Based Costing”, Harvard Business Review, May - Jun, Vol. 69, No. 3,pps. 130-135. 
Cooper, Robin - Kaplan, Robert S. (1992), “Activity-based Systems: Measuring the Costs of Resource Usage”, Accounting Horizons, Vol. 6, No. 3, pp. 1-13.

Çapuk, Selçuk (2012), "Bir Havayolu Şirketinde Zaman Etkenli Faaliyet Tabanlı Maliyet Uygulaması”, Marmara Üniversitesi Sosyal Bilimler Enstitüsü, İstanbul.

Ecer, Fatih (2007), “Üyelik Fonksiyonu Olarak Üçgen Bulanık Sayılar mı Yamuk Bulanık Sayılar mı?, “Gazi Üniversitesi İktisadi ve İdari Bilimler Fakültesi Dergisi Cilt. 9. Sayı 2, ss. 161-180.

Ertuğrul, İrfan - Karakaşoğlu, Nilsen (2008), “Bulanık PERT Yaklaşımlarının Makine Üretim Sürecinde Karşılaştırılması”, Dokuz Eylül Üniversitesi İktisadi ve İdari Bilimler Fakültesi Dergisi, Cilt 23, Sayı 1, ss. 109-124.

Everaert, Patricia- Bruggeman, Werner - Sarens, Gerrit - Anderson, Steven R. - Levant, Yves (2008), "Cost Modeling İn Logistics Using Time-Driven ABC: Experiences from a Wholesaler”, International Journal of Physical Distribution \& Logistics Management, Vol 38, No 3, pp. 172-191.

Gençoğlu, Ümit Gücenme (2008), Türkiye Muhasebe Standartları ile Uyumlu Maliyet Muhasebesi, MKM Yayıncilık, Bursa.

Horngren, Charles T. - Datar, Srikant M. - Rajan, Madhav V. (2012), Cost Accounting A Managerial Emphasis”, Fourteenth Edition, Pearson, Global Edition.

Kaplan, Robert S. - Anderson, Steven R. (2003), “Time-Driven Activity Based Costing”, Working Papers Series, November, pp. 1-18.

Kaplan, Robert S. - Anderson, Steven R. (2004), “Time-Driven Activity-Based Costing,” Harvard Business Review, Vol.82, No.11, pp. 131-138.

Karakaşoğlu, Nilsen (2008), "Bulanık Çok Kriterli Karar Verme Yöntemleri ve Uygulama" Pamukkale Üniversitesi Sosyal Bilimler Enstitüsü, Denizli.

Karataş, Özlem Nilüfer (2011), "Bulanık Faaliyet Tabanlı Maliyetleme Yaklaşımı ve Bir Uygulama”, Süleyman Demirel Üniversitesi Sosyal Bilimler Enstitüsü, Isparta.

Karğın, Sibel (2013), "Faaliyet Tabanlı Maliyetleme Yönteminin Yükselişi ve Düşüşü", Muhasebe ve Finansman Dergisi, Sayı. 58, Nisan, ss. 21-40.

Kırlığlu, Hilmi - Atalay, Bedia (2014), "Sürece Dayalı Faaliyet Tabanlı Maliyetlemenin Kapasite Yönetimi Açısından Değerlendirilmesi ve Bir Hastane Uygulaması", Uluslararası Yönetim İktisat ve İşletme Dergisi, Cilt 10, Sayı 23, ss. 99-119.

Mortaji, Seyed Taha Hossein - Bagherpour, Morteza - Mazdeh, Mohammad Mahdavi (2013), “Fuzzy Time-Driven Activity-Based Costing”, Engineering Management Journal, Vol. 25, No 3, pp. 63-73.

Nachtmann, Heather - Needy, Kim LaScola (2001), "Fuzzy Activity Based Costing: A Methodology For Handling Uncertainty İn Activity Based Costing Systems”, The Engineering Economist, Vol. 46, No 4, pp. 245-273. 
Özyürek, Hamide - Dinç, Yusuf (2014), "Son Yıllarda Maliyet Dağıtımında Kullanılan Yöntemler ve Zamana Dayalı Faaliyet Tabanlı Maliyetleme Olay Çalışması”, C.Ü. İktisadi ve İdari Bilimler Dergisi, Cilt 15, Sayı 1, ss. 345-364.

Sarokolaei, Mehdi Alinezhad. - Saviz, Mohsen - Moradloo, Mehdi Fathi - Dahaj, Najmeh. Soleimani (2013), "Time Driven Activity Based Costing by Using Fuzzy Logics”, Procedia-Social and Behavioral Sciences, 75, pp. 338-345.

Siguenza-Guzman, Lorena - Van den Abbeele, Alexandra - Vandewalle, Joos - Verhaaren, Henri - Cattrysse, Dirk (2014), "Using Time-Driven Activity-Based Costing to Support Library Management Decisions: A Case Study For Lending And Returning Processes”, The Library Quarterly, Vol 23, № 3, pp. 76-98.

Tuş, Ayşegül (2006), "Bulanık Doğrusal Programlama ve Bir Üretim Planlamasında Uygulama Örneği”, Pamukkale Üniversitesi Sosyal Bilimler Enstitüsü, Denizli.

Yükçü, Süleyman - Seçkin Gönen (2009), "Zaman Esaslı Faaliyete Dayalı Maliyetleme Yaklaşımının Otomobil Parçaları Üreten Bir İşletmede Uygulanması", Muhasebe ve Denetime Bakış, Nisan 21, ss. 19-32.

Zadeh, Lotfi A. (1965), “Fuzzy sets”, Information and control, Vol.8, No.3,pp. 338-353. 